\title{
Multidrug resistant $E$. coli recovered from household reared female budgerigar pet bird (Melopsittacus undulatus) in Ibadan, Oyo State Nigeria: a case report
}

\author{
Adelekan Oluseyi Okunlade ${ }^{1^{*}}$ (]), Oluwaseun Olanrewaju Esan² and Akinlabi Oladele Ogunleye ${ }^{1}$
}

\begin{abstract}
Background: Pet birds are housed and reared exclusively for ornamental use. These include psittaciformes (parrots, parakeets, budgerigars, love birds) and passeriformes (e.g. canaries, finches, sparrows, also called songbirds). E. coli is a Gram negative bacterium. In birds, it is called Avian Pathogenic E. coli and is a causative agent of avian colibacillosis. Antimicrobial resistance is the process through which bacteria evade the activity of antibiotics. According to WHO (World Health Organization), antibiotic resistance is the result of indiscriminate use of these drugs which are used both in Veterinary and human medicine.
\end{abstract}

Case presentation: A one and half year old yellow female budgerigar pet bird (Melopsittacus undulatus) with patches of black and white on wings and back, kept as companion (one out of four) was presented dead at the avian clinic section of the Veterinary Teaching Hospital, University of Ibadan, Nigeria. It was reported to have presented signs of anorexia and diarrhea for two days before death. Provisional diagnosis was colibacillosis. Intestinal samples were sent for microbial culture and sensitivity. The samples yielded growth of E. coli. Antimicrobial susceptibility revealed that the organism showed resistance to all tested antibiotics.

Conclusions: Multidrug-resistant Escherichia coli constitutes a major public health concern. The constant interaction between household companion birds and humans gives room for disease transmission. Wild birds kept as pets or companions harbor pathogenic and zoonotic pathogens, hence a threat to public health.

Keywords: Colibacillosis, Melopsittacus undulatus, Multidrug resistant E. coli, Case report

\section{Background}

Companion birds are considered the third most common pets after cats and dogs. As close friends of humans, they play an important role in human life (Cong et al. 2014). They are kept in confinement and reared for ornamental use. These birds include psittaciformes (parrots, parakeets, budgerigars, love birds) and passeriformes (e.g. canaries, finches, sparrows, also called songbirds) (Tully

\footnotetext{
*Correspondence: dr_seyi@yahoo.com

${ }^{1}$ Department of Veterinary Microbiology, Faculty of Veterinary Medicine,

University of Ibadan, Ibadan, Nigeria

Full list of author information is available at the end of the article
}

2009). Most caged birds have been reported to belong to order Passeriformes which include canaries, finches, and order Psittaciformes which include parrots, parakeets, and lovebirds (Boseret et al. 2013). Melopsittacus undulatus is popularly called a parakeet in America. It has a greenish body, yellow head and wings speckled with black. It can be easily trained to "talk." Budgerigars are often presented with digestive problems because they regurgitate their seed or a white pasty substance (Nigel 2009). Antimicrobial resistance is a public health issue (Argudín et al. 2017). Household pets are of zoonotic importance and carry multidrug-resistant (MDR) 
bacteria. As many authors have emphasized, there can be transmission of antimicrobial resistant genes from animals to man and vice versa. This can be via contact, contaminated food or the environment (Damborg et al. 2016; Argudín et al. 2017; Pomba et al. 2017). Indiscriminate use of antibiotics may increase existing populations of microorganisms that are antimicrobial resistant. These microorganisms contaminate environment, soil, food and aquatic environment as they are shed in feaces. Migrating and non-migrating wild birds with existing bacteria of potential zoonotic importance pose a great threat to public health. Many pathogenic bacteria species have been isolated from wild birds. Migrating and non-migrating wild birds can also act as reservoirs of coliform bacteria, such as E. coli. The organisms are carriers of antimicrobial-resistance genes (Shobrak et al. 2014). Clinically, E. coli is an important Gram-negative bacterium which has potential of causing serious diseases such as urinary tract infections (UTIs), pyelonephritis and bacteremia (Jacobsen et al. 2008).

Wild birds (Migrating and non-migrating) or general wild animals could therefore serve as reservoirs of resistant bacteria and genetic factors of antimicrobial resistance (Dolejska et al. 2009). Several workers have reported isolation of multidrug resistant of $E$. coli from companion birds (Borges et al. 2017; Belgi et al. 2019). This current case reports recovery of multidrug resistant E. coli from budgerigar pet bird (Melopsittacus undulatus).

\section{Case presentation}

A one and half year old yellow female budgerigar pet bird (Melopsittacus undulatus) with patches of black and white on wings and back, kept as companion (one out of four) was presented dead at the avian clinic section of the Veterinary Teaching Hospital (VTH), University of Ibadan, Nigeria. History revealed that the owner acquired the four birds four months earlier. Two of the birds had died 3 weeks post arrival without the owner notifying a Veterinary facility. The owner maintains an aviary consisting of parrots which include African grey parrots, Senegal parrots, canaries, love birds and pea fowls. All the different species are housed separately in cages within the living room with the exception of the pea fowls that are housed beside the main building.

The bird was noticed to have shown signs of anorexia and diarrhea for a period of two days prior death. Ethical approval was obtained for this case from Ethical Committee of the University of Ibadan with the IRB Number: $\mathrm{UI} / \mathrm{EC} / 21 / 0438$.

\section{Post Mortem lesions}

There was pasted vent with yellowish diarrhea; there was moderate dehydration of the carcass with empty crop.
The liver was observed to be slightly swollen and congested. The small intestine contained moderate quantity of whitish mucoid fluid while there were impacted dry feacal materials occluding a substantial portion of the colon and the cloaca. The kidneys appeared moderately pale with prominent ureter. Intestinal samples (both small and large) were sent to the laboratory for microbial culture and sensitivity. Duodenal and colon parts of the intestine were cultured on blood agar and incubated for $24 \mathrm{~h}$ at $37{ }^{\circ} \mathrm{C}$. Suspected colonies were then inoculated onto MacConkey agar and incubated for $24 \mathrm{~h}$ at $37^{\circ} \mathrm{C}$. Lactose fermenters were stained with Gram's staining, tested with indole reaction and motility was carried out. Gram's reaction showed a Gram negative rod shaped organism, indole positive and actively motile. Colonies that appeared pinkish were subcultured onto Eosine Methylene blue agar (EMB) and incubated for $24 \mathrm{~h}$ at $37{ }^{\circ} \mathrm{C}$. Colonies that have greenish metallic sheen colouration on EMB agar were considered for API (Analytic Profile Index) identification. The E. coli was finally confirmed from the result of API 20 E kit. Seven digit profile number (6 440552 ) was generated indicating $E$. coli. The same $E$. coli strains were recovered from the samples. Antibiogram of the isolate was determined by KirbyBauer disk diffusion method using the following antibiotics: septrin $30 \mu \mathrm{g}$, chloramphenicol $30 \mu \mathrm{g}$, sparfloxacin $10 \mu \mathrm{g}$, ciprofloxacin $10 \mu \mathrm{g}$, amoxicillin $30 \mu \mathrm{g}$, augumentin $30 \mu \mathrm{g}$, gentamycin $10 \mu \mathrm{g}$, pefloxacin $30 \mu \mathrm{g}$, tarivid $10 \mu \mathrm{g}$ and streptomycin $30 \mu \mathrm{g}$. Results were analysed based on 2021 CLSI guidelines. It was interesting to note that the recovered $E$. coli showed resistance to all the listed antibiotics. Further to this, DNA extraction and PCR were carried out on the isolate using Plasmid-mediated Quinolone Resistance gene primers; A, B, D and S. (Table 1). The E. coli sample amplified QNRA and negative for others. This shows the presence of quinolone resistant gene in the isolate (Fig. 1). The isolate was then sent for partial sequencing. The nucleotide sequences determined have been deposited in the Genbank and the assigned accession number was -MZ618641.

\section{Discussions}

Escherichia coli is responsible for bloodstream infections worldwide (Kern and Rieg 2020). It resides in the gut and causes no harm, but can cause severe and life-threatening infections when there is weakened immune system. The current case of multidrug resistant $E$. coli shows similarity with the work of Siquerira et al. (2017) who recovered E. coli from intestine of nine Melopsittacus undulatus in Brazil. Marietto-Gonçalves et al. (2017) also described avian colibacillosis in a pet Amazona aestiva from which $E$. coli was isolated from many organs. Since early 2000s, there has been a steady increase of antibiotic resistance 
Table 1 Primers for Quinolone Resistant genes A, B, D and S

\begin{tabular}{|c|c|c|c|}
\hline Primers & Expected band size (bp) & Annealing temperature $\left({ }^{\circ} \mathrm{C}\right)$ & References \\
\hline $\begin{array}{l}\text { QNRA-F ATTTCTCACGCCAGGATTTG } \\
\text { R GATCGGCAAAGGTTAGGTCA }\end{array}$ & 516 & 55 & Robicsek et al. (2006) \\
\hline $\begin{array}{l}\text { QNRB-F GATCGTGAAAGCCAGAAAGG } \\
\text { R-ACGATGCCTGGTAGTTGTCC }\end{array}$ & 469 & 49 & Robicsek et al. (2006) \\
\hline $\begin{array}{l}\text { QNRD-F-CGAGATCAATTTACGGGGAATA } \\
\text { R-AACAAGCTGAAGCGCCTG }\end{array}$ & 582 & 53 & Pribul et al. (2017) \\
\hline $\begin{array}{l}\text { QNRS-F - ACGACATTCGTCAACTGCAA } \\
\text { R -TAAATTGGCACCCTGTAGGC }\end{array}$ & 417 & 53 & Robicsek et al. (2006) \\
\hline
\end{tabular}

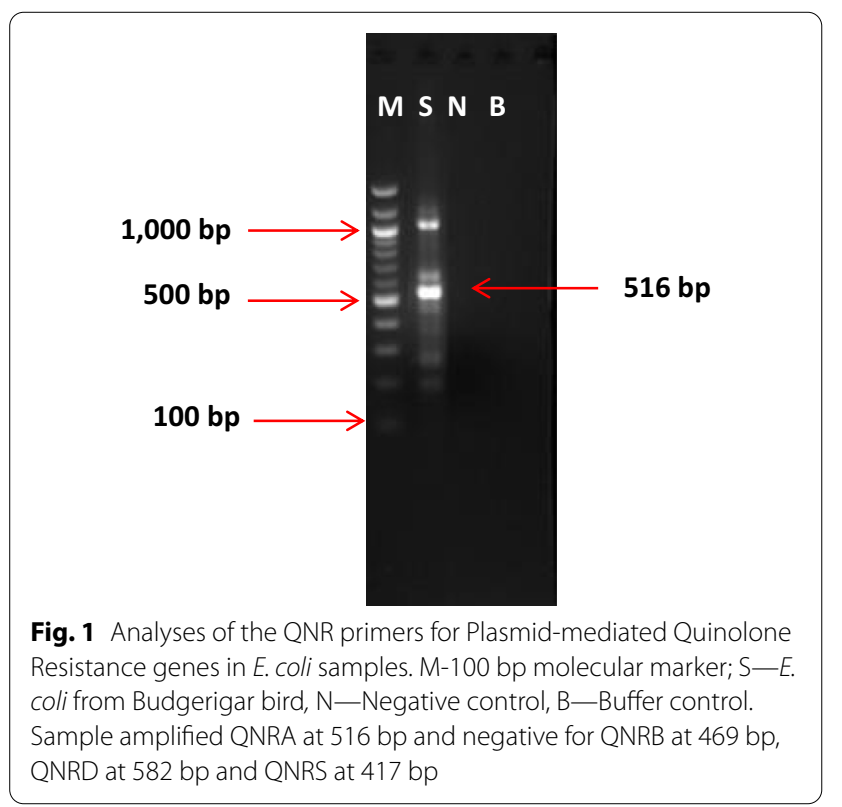

in E. coli despite attempts to control it. Resistance to multiple antibiotics is on the increase as far as E. coli is concerned (Satlin et al. 2018). E. coli becomes a multidrug resistant isolate when found to be non-susceptible to more than two different antimicrobial agent classes. Multidrug E. coli isolated from budgerigar bird in this case was found to be resistant to all antibiotics tested. This phenomenon may be attributed to abuse of antibiotics use in avian medicine. Plasmids carrying qnr genes have been known to transmit quinolone resistance (MartinezMartinez et al. 1998). The geographical distribution of $q n r A$ genes has been found to be wide (Nordmann and Poirel 2005), while those of the newer qnr types, qnrB (Jacoby et al. 2006) and qurS (Hata et al. 2005), have not been studied. Detection of qnrA in this case study supports the findings of Robicsek et al. (2006) who also detected qnrA in $E$. coli isolates and reported absence of qnrS.

The multidrug resistant E. coli reported in this case also raises a public health concern in as much as the birds interact with their owner and other humans within the household and in market shops in some cases. Children and immunocompromised patients are at a very high risk of infection if they come in contact with secretions or droppings from this type of birds. Findings from this case suggest that with constant human interaction with budgerigars reared in households, there can be contamination of food, water and environment since they have been found to harbor pathogenic organisms especially the multidrug resistant strains.

\section{Conclusions}

This case has corroborated earlier reports that wild birds kept as pets or companions harbor pathogenic and zoonotic pathogens. With this, unregulated movements of birds could be a factor in introducing zoonotic pathogens and their vectors in non-endemic countries. We recommend provision of adequate information and prevention tools by the bird breeders to those they sell or give their birds to. Also, there is need for better enlightenment by veterinarians on dangers of infectious bird diseases. If an uncommon sign of infection or sudden death occurs, the owners should quickly report to their avian veterinarian.

\section{Abbreviations}

APEC: Avian pathogenic Escherichia coli; WHO: World Health Organisation; VTH: Veterinary Teaching Hospital; MDR: Multidrug resistant; AMR: Antimicrobial resistance; EMB: Eosine methylene blue; API: Analytic Profile Index; CLSI: Clinical laboratory standard institute; DNA: Deoxyribonucleic acid; PCR: Polymerase chain reaction; QNR: Quinolones resistance.

\section{Acknowledgements}

The authors acknowledge the support of the pet bird owner and Dr. A. O. Adediji (Department of Crop Protection and Environmental Biology, University of Ibadan) for molecular assistance.

\section{Authors' contributions}

EOO carried out the postmortem examination and contributed in writing the manuscript, OAO carried out the laboratory analysis and prepared the manuscript while OAO supervised the case as consultant. Final manuscript was read by all authors and approved for publication. All authors read and approved the final manuscript. 


\section{Funding}

None.

\section{Availability of data and materials}

Not applicable.

\section{Declarations}

\section{Ethics approval and consent to participate}

Ethical approval was obtained from the University of Ibadan Ethical Committee with IRB Number: UI/EC/21/0438.

\section{Consent for publication}

Written consent to publish the case was obtained from the pet owner.

\section{Competing interests}

The authors declare that they have no competing interests.

\section{Author details}

${ }^{1}$ Department of Veterinary Microbiology, Faculty of Veterinary Medicine, University of Ibadan, Ibadan, Nigeria. ${ }^{2}$ Department of Veterinary Medicine, Faculty of Veterinary Medicine, University of Ibadan, Ibadan, Nigeria.

Received: 29 July 2021 Accepted: 9 September 2021

Published online: 17 September 2021

\section{References}

Argudín MA, Deplano A, Meghraoui A, Dodémont M, Heinrichs A, Denis O, Nonhoff C, Roisin S (2017) Bacteria from animals as a pool of antimicrobial resistance genes. Antibiotics 6(2):12. https://doi.org/10.3390/antib iotics6020012

Belgi DS, Baran C, Baris H, Cemal AM, Ilgin K, Kemal M, Serkan I, Funda BA, Yakut ON, Seyyal A, Beren BK (2019) Antimicrobial resistance profiles of Escherichia coli isolated from companion birds. J King Saud Univ Sci 32(1):1069-1073. https://doi.org/10.1016/j.jksus.2019.09.014

Borges CA, Beraldo LG, Maluta RP, Cardozo MV, Barboza VE, Guastalli VS, Kariyawasam S, DebRoy C, Ávila FA (2017) Multidrug-resistant pathogenic Escherichia coli isolated from wild birds in a veterinary hospital. Avian Pathol 46(1):76-83. https://doi.org/10.1080/03079457.2016.1209298

Boseret G, Losson B, Mainil JG, Etienne T, Claude S (2013) Zoonoses in pet birds: review and perspectives. Vet Res 44:36. https://doi.org/10.1186/ 1297-9716-44-36

Cong W, Huang SY, Zhang XX, Zhou DH, Xu MJ, Zhao Q, Zhu XQ (2014) Chlamydia psitacci exposure in pet birds. J Med Microbiol 63(4):578-581. https://doi.org/10.1099/jmm.0.070003-0

Damborg P, Broens EM, Chomel BB, Guenther S, Pasmans F, Wagenaar JA, Weese JS, Wieler LH, Windahl U, Vanrompay D, Guardabassi L (2016) Bacterial zoonoses transmitted by household pets: state-of-the-art and future perspectives for targeted research and policy actions. J Comp Pathol 155(1/S1):S27-S40. https://doi.org/10.1016/j.jcpa.2015.03.004

Dolejska M, Bierosova B, Kohoutova L, Literak I, Cizek A (2009) Antibioticresistant Salmonella and Escherichia coli isolates with integrons and extended-spectrum beta-lactamases in surface water and sympatric black-headed gulls. J Appl Microbiol 106:1941-1950. https://doi.org/10 1111/j.1365-2672.2009.04155

Hata M, Suzuki M, Matsumoto M, Takahashi M, Sato K, Ibe S, Sakae K (2005) Cloning of a novel gene for quinolone resistance from a transferable plasmid in Shigella flexneri 2b.Antimicrob. Agents Chemother 49:801-803. https://doi.org/10.1128/AAC.49.2.801-803.2005

Jacobsen SM, Stickler DJ, Mobley HL, Shirtliff ME (2008) Complicated catheterassociated urinary tract infections due to Escherichia coli and Proteus mirabilis. Clin Microbiol Rev 21(1):26-59. https://doi.org/10.1128/CMR. 00019-07

Jacoby GA, Walsh KE, Mills DM, Walker VJ, Robicsek A, Hooper DC (2006) anrB, another plasmid-mediated gene for quinolone resistance. Antimicrob Agents Chemother 50:1178-1182. https://doi.org/10.1128/AAC.50.4. 1178-1182.2006

Kern WV, Rieg S (2020) Burden of bacterial bloodstream infection: a brief update on epidemiology and significance of multidrug-resistant pathogens. Clin Microbiol Infect 26:151-157. https://doi.org/10.1016/j.cmi. 2019.10 .031

Marietto-Gonçalves GA, Lima ET, Siqueira JL, Andreatti-Fiho RL (2017) Colisepticemia em papagaio-verdadeiro (Amazona aestiva). Revta Bras Saúde Prod Anim 8(1):56-60. https://doi.org/10.1590/S0100-736X20170004000 12

Martinez-Martinez L, Pascual A, Jacoby GA (1998) Quinolone resistance from a transferable plasmid. Lancet 351:797-799. https://doi.org/10.1016/S01406736(97)07322-4

Nigel H (2009) Psittacine birds. In: Handbook of avian medicine, pp 138-168. https://doi.org/10.1016/B978-0-7020-2874-8.00007-9

Nordmann P, Poirel L (2005) Emergence of plasmid-mediated resistance to quinolones in Enterobacteriaceae. J Antimicrob Chemother 56:463-469. https://doi.org/10.1093/jac/dki245

Pomba C, Rantala M, Greko C, Baptiste KE, Catry B, Van Duijkeren E, Sanders $P$ (2017) Public health risk of antimicrobial resistance transfer from companion animals. J Antimicrob Chemother 72(4):957-968. https://doi. org/10.1093/jac/dkw481

Pribul BR, Festivo ML, de Souza MM, Rodrigues DP (2017) Characterization of quinolone resistance in Salmonella spp isolates from food products and human samples in Brazil. Braz J Microbiol 47(1):196-201. https://doi.org/ 10.1016/j.bjm.2015.04.001

Robicsek A, Strahilevitz J, Sahm DF, Jacoby GA, Hooper DC (2006) qnr prevalence in ceftazidime-resistant Enterobacteriaceae isolates from the United States. Antimicrob Agents Chemother 50(8):2872-2874. https:// doi.org/10.1128/AAC.01647-05

Satlin MJ, Chavda KD, Baker TM, Chen L, Shashkina E, Soave R, Small CB, Jacobs SE, Shore TB, van Besien K, Westblade LF, Schuetz AN, Fowler VG Jr, Jenkins SG, Walsh TJ, Kreiswirth BN (2018) Colonization with levofloxacinresistant extended-spectrum $\beta$-lactamase-producing Enterobacteriaceae and risk of bacteremia in hematopoietic stem cell transplant recipients. Clin Infect Dis 67:1720-1728. https://doi.org/10.1093/cid/ciy363

Shobrak MY, Abo-Amer AE (2014) Role of wild birds as carriers of multidrug resistant Escherichia coli and Escherichia vulneris. Braz J Microbiol 45(4):1199-1209. https://doi.org/10.1590/s1517-83822014000400010

Siqueira AS, Maciel WC, Vasconcelos RH, Bezerra GA, Lopes ES, Machado DN, Lucena M, Lucena FR (2017) Pathologic and microbiologic aspects of pet psittacine infected by Escherichia coli and Salmonella Typhimurium. Pesquisa Veterinária Brasileira 37(4):79-384. https://doi.org/10.1590/ S0100-736X2017000400012

Tully TN (2009) Birds: manual of exotic pet practice. Elsevier, St. Louis, pp 250-298

\section{Publisher's Note}

Springer Nature remains neutral with regard to jurisdictional claims in published maps and institutional affiliations. 